University of Montana

ScholarWorks at University of Montana

10-1998

\title{
Grizzly Bear Digging: Effects on Subalpine Meadow Plants in Relation to Mineral Nitrogen Availability
}

\author{
Sandra E. Tardiff \\ Jack Arthur Stanford \\ The University of Montana, jack.stanford@umontana.edu
}

Follow this and additional works at: https://scholarworks.umt.edu/biosci_pubs

Part of the Biology Commons

Let us know how access to this document benefits you.

\section{Recommended Citation}

Tardiff, Sandra E. and Stanford, Jack Arthur, "Grizzly Bear Digging: Effects on Subalpine Meadow Plants in Relation to Mineral Nitrogen Availability" (1998). Biological Sciences Faculty Publications. 315.

https://scholarworks.umt.edu/biosci_pubs/315

This Article is brought to you for free and open access by the Biological Sciences at ScholarWorks at University of Montana. It has been accepted for inclusion in Biological Sciences Faculty Publications by an authorized administrator of ScholarWorks at University of Montana. For more information, please contact scholarworks@mso.umt.edu. 


\title{
GRIZZLY BEAR DIGGING: EFFECTS ON SUBALPINE MEADOW PLANTS IN RELATION TO MINERAL NITROGEN AVAILABILITY
}

\author{
SANDRA E. TARDIFF AND JACK A. STANFORD \\ Flathead Lake Biological Station, University of Montana, 311 Bio Station Lane, Polson, Montana 59860-9659 USA
}

\begin{abstract}
Grizzly bears (Ursus arctos horribilis) affect plant distributions and mineral nitrogen availability when they forage by digging for the bulbs of glacier lilies (Erythronium grandiflorum) growing in subalpine meadows of Glacier National Park, Montana, United States. Our working hypothesis is that grizzly bears structure plant communities and influence nitrogen availability when they selectively dig for preferred plants. In this paper, we report on differences found in recently disturbed digs $(<5 \mathrm{yr}$ old $)$ when compared to adjacent, undisturbed meadow.

We used ion exchange resin bags to determine the availability of mineral nitrogen in grizzly bear digs compared to undisturbed meadow. Soil in digs contained significantly more ammonium-N and nitrate- $\mathrm{N}$ than adjacent, intact meadow. Glacier lily bulbs revegetating bear digs had higher tissue nitrogen and water-soluble carbohydrate concentrations than lilies in undisturbed meadow. Mature glacier lilies in digs produced twice as many seeds as did those in adjacent meadow. Glacier lily seedlings establish best on bare mineral soil, which in these meadows is found primarily in bear digs. Therefore, grizzly bear digging may benefit old, deeply seated plants that survive digging and reproduce. Digs overlapped spatially, meaning that grizzly bears were returning to dig in patches disturbed in previous years, perhaps in response to easier digging conditions and more nutritious glacier lily bulbs.

To test the idea that the observed increase in mineral nitrogen was due to the physical disturbance of grizzly bear digging and not bear choice of sites already high in nitrogen or bear excretion, we created experimental digs. Ammonium- $\mathrm{N}$ and nitrate-N levels increased significantly following our digging treatment, just as we had observed in the natural bear digs. Although we do not know how a bear chooses an initial digging site, this disturbance has the potential for influencing long- and short-term plant community structure.

Key words: digging; disturbance; Erythronium grandiflorum; glacier lily; Glacier National Park; grizzly bear; nitrogen; patch dynamics; plant-animal interaction; positive interaction; subalpine; Ursus arctos.
\end{abstract}

September 1824 . . we observed at some distance the appearance of a ploughed field, and riding up towards it, found a large piece of ground more than four acres in extent, dug up and turned over. On getting to the spot, we observed no less than nine ... grizzly bears at work, rooting away.

-A. Ross, Stanley Basin, Idaho, USA

\section{INTRODUCTION}

The diversity of interactions between organisms is beginning to be explicitly recognized as one of the components of biological diversity (Thompson 1996). Understanding the effects of a particular interaction on population dynamics or relevant ecosystem processes is a major challenge for ecologists (Jones and Lawton 1995). Underlying this focus is the knowledge that many biological interactions no longer occur as species go extinct or are displaced from significant portions of

Manuscript received 14 April 1997; revised 1 December 1997; accepted 18 December 1997. their former range, thereby decreasing the number of species that are interacting. The community context in which interactions take place is very important to understanding the implications of any interaction, and this is likewise being altered (Thompson 1994).

The role of organisms in modifying ecosystems through disturbance is well documented as a dynamic, structuring force in ecological systems (BioScience 1988, Jones et al. 1994). Herbivory, one type of organismal disturbance, has the potential to positively or negatively affect particular forage species, depending on the system, species, and the intensity and timing of herbivory (Paige and Whitham 1987, Maschinski and Whitham 1989, Huntly 1991, Paige 1992). Ecosystem processes, such as nutrient cycling, often are affected in turn (Pastor and Naiman 1992, Jones et al. 1994).

Plant and soil microbial communities may be expected to react to herbivory. Herbivores select plant material with a low $\mathrm{C}: \mathrm{N}$ ratio because it is easiest to digest (Mattson 1980). Organic material with low C:N is also easiest for microbes to decompose. As herbivores preferentially remove plant material with a low 
$\mathrm{C}: \mathrm{N}$ ratio, material with higher $\mathrm{C}: \mathrm{N}$ is returned to the soil. Thus, the amount of $\mathrm{N}$ available to microbial decomposers decreases, and they become $\mathrm{N}$ limited (Kaye and Hart 1997). Microbes compete with plants for inorganic $\mathrm{N}$; as that pool decreases, $\mathrm{N}$ becomes more limiting to the plant community. Plant species with a higher $\mathrm{C}: \mathrm{N}$ ratio are favored, and those species with lower $\mathrm{C}: \mathrm{N}$ decrease in the community, continuing the spiral of decline in soil nitrogen (Pastor and Naiman 1992). For example, preferred plant species decrease in abundance after moose herbivory, followed by a decrease in soil mineral nitrogen (Pastor et al. 1993). Alternatively, a forage species may exhibit compensatory growth, resulting in a higher seed set than that of nonbrowsed plants (Paige and Whitham 1987). When burrowing accompanies herbivory, as with fossorial mammals, an increase in mineral nitrogen in the burrow vicinity may occur; a number of mechanisms are thought to be responsible for this increase in soil nutrients, including changes in soil moisture and temperature, microbial mineralization rates, and plant nitrogen uptake (Huntly and Inouye 1988, Whicker and Detling 1988). The burrow plant community may differ dramatically from adjacent, undisturbed areas by containing species rarely found at undisturbed sites (Platt and Weis 1977). Such influences on plant composition may affect foraging patterns of other organisms, such as bison (Bison bison) and pronghorn antelope (Antilocapra americana), which preferentially graze within prairie dog (Cynomys ludovicianus) towns (Coppock et al. 1983, Krueger 1986).

Grizzly bears (Ursus arctos horribilis) forage by digging for a variety of starchy plant roots, small mammals, and insects (Ross 1855, Chapman et al. 1953, Singer 1978, Craighead and Mitchell 1982, Kendall 1983, Servheen 1983, Holcroft and Herrero 1984, Mace and Jonkel 1986, Hamer and Herrero 1987, Phillips 1987, Edge et al. 1990, Hamer et al. 1991, Mattson et al. 1991, Mattson 1997). However, the consequences of grizzly bear digging on the distribution and abundance of plant species, soil nutrient availability, and successional patch dynamics have not been investigated. Because they are large, wide-ranging omnivores, bears have an inherently high potential to affect many other organisms and ecosystem processes. Because grizzly bears occupy a small fraction of their former range in the lower 48 states, the present diversity of their interactions is limited compared to its historical extent. Where bears remain, understanding their influences may be critical to management, as well as to the basic ecological implications of their behaviors.

Disturbances caused by grizzly bears foraging for plant roots could have pervasive effects on the local plant assemblage, initially by changing species' distributions and abundances and soil mineral nitrogen concentrations, and ultimately by changing successional patterns within disturbed patches. If preferred forage species revegetate digs, they could be larger and/ or more nutritious as a consequence of disturbance effects that would minimize plant competition and potentially increase soil nutrient availability. Competition would be minimized because of the decrease in the number of plants growing in a dig. Available nitrogen could increase for a variety of reasons, including the following: increased mineralization rates due to physical disturbance of the soil, decreased uptake by plants, and increased mineralization of organic material, such as grizzly bear excrement. This scenario of larger and/ or more nutritious plant foods might encourage grizzly bears to selectively dig in previously disturbed areas. Moreover, the patch mosaic created by grizzly bear digging over time would also affect other organisms living within the ecosystem.

Our long-term goal in this study is to understand the impact of grizzly bear digging for glacier lily (Erythronium grandiflorum Pursh; Liliaceae) bulbs in subalpine meadows, on both spatial (meadow-wide) and temporal (decades) scales. Here, we report the initial effect of bear digging on availability of soil mineral nitrogen and on glacier lily ecology by comparing recent digs ( $<5 \mathrm{yr}$ old $)$ to adjacent, undisturbed meadow. Specifically, we examine the following predictions: (1) soil in bear digs will have greater mineral nitrogen $\left(\mathrm{NH}_{4}^{+}-\mathrm{N}\right.$ and $\left.\mathrm{NO}_{3}^{-}-\mathrm{N}\right)$ availability than soil in undisturbed meadow; (2) glacier lilies in digs will contain higher concentrations of nitrogen and carbohydrates; (3) glacier lilies growing in bear digs will produce more seeds than lilies in adjacent, intact meadow; (4) experimental digs will mimic bear digs in their mineral nitrogen dynamics.

\section{STUdy AREA}

Grizzly bears produce patches of tilled soil when they forage for glacier lily bulbs in subalpine $(\sim 2000$ $\mathrm{m}$ a.s.1.) meadows of Glacier National Park (GNP), Montana, United States (Fig. 1). Individual digs sometimes cover $>15 \mathrm{~m}^{2}$. Glacier lilies are long-lived spring ephemerals that are thought to require $\geq 8$ yr to reach sexual maturity (Kawano et al. 1982). This species does not often reproduce vegetatively, although other species of Erythronium do (Thomson et al. 1996). They flower in the first weeks after snow melt and senesce and dehisce seeds prior to the majority of bear activity, which occurs in these meadows from mid-August into October (avalanche chutes are not included in our study). When digging for bulbs, the bears turn over chunks of sod at a fairly uniform depth of $\sim 10 \mathrm{~cm}$ (the maximum depth of the majority of roots), exposing bulbs that are then nipped off. Chunks of sod are left intact by the bears, so many glacier lily bulbs and fragments remain to resprout in the following year.

Research in GNP was conducted at three adjacent meadows (Lower, Middle, and Upper) located near the continental divide at Logan Pass $\left(48^{\circ} 41^{\prime} \mathrm{N}, 113^{\circ} 43^{\prime}\right.$ $\mathrm{W}, \sim 2000 \mathrm{~m}$ a.s.l). The plant assemblage of these moist, but well-drained, meadows is characterized by 


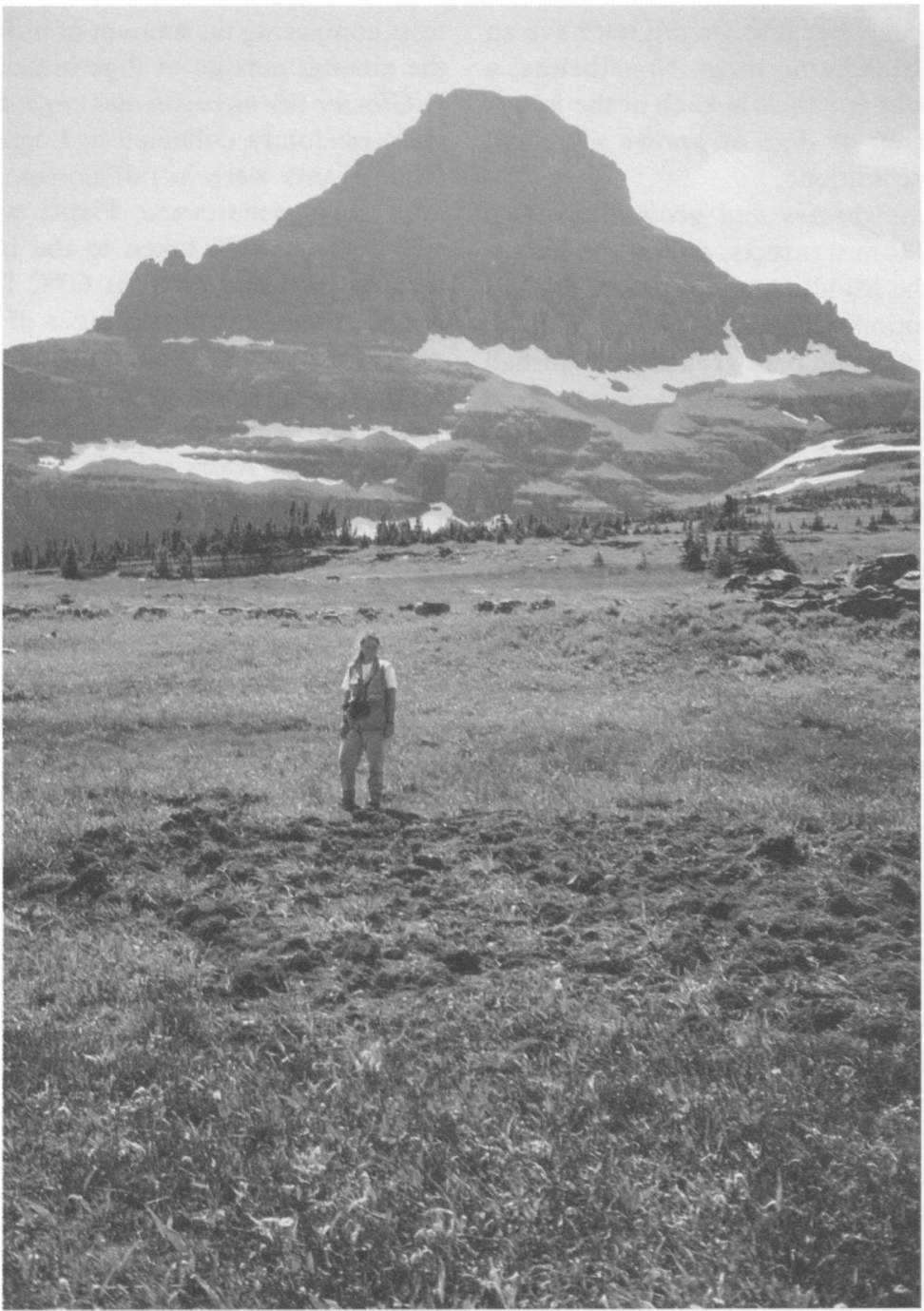

FIG. 1. A patch formed on the subalpine meadow landscape of Glacier National Park, Montana, United States by a grizzly bear digging for glacier lily bulbs. The photo shows a fresh dig created in the glacier lily-carpeted meadow. This dig is $\sim 15$ $\mathrm{m}^{2}$ and is in the Lower Meadow of our Logan Pass study site (see Study area).

glacier lilies, smooth woodrush (Luzula hitchcockii), sedges (Carex spp.), creeping sibbaldia (Sibbaldia procumbens), and western St. John's-wort (Hypericum formosum) (Choate and Habeck 1967, Hartley 1976). Small islands of subalpine fir (Abies lasiocarpa) also occur in these meadows, as well as scattered white bark pine (Pinus albicaulis). All are native plants. A second study site was located at Preston Park, GNP (48 $43^{\prime}$ $\mathrm{N}, 113^{\circ} 38^{\prime} \mathrm{W}, \sim 2000 \mathrm{~m}$ a.s.l.), where subalpine meadow islands are interspersed between forests of subalpine fir and white bark pine. Most precipitation at Logan Pass and Preston Park occurs as snow, and meadows are snow covered from October to July in most years. Summers generally are cool and wet, with some hot, dry periods. Annual precipitation is $250 \mathrm{~cm}$ and temperature varies from $3^{\circ} \mathrm{C}$ to $27^{\circ} \mathrm{C}$, June to October; the average is $10^{\circ} \mathrm{C}$ (Choate and Habeck 1967).

\section{Methods}

Meadow and bear dig mapping.-All grizzly bear digs in each of the three meadows at Logan Pass were surveyed using a Topcon AT-F6 Autolevel (Topcon Instruments Corporation of America, Paramus, New Jersey, USA) during 1994 (before that year's digging season). Digs from 1992 (but no older) were easily distinguished from the freshly tilled areas of 1993. Maps were made of each meadow, using angle and distance coordinates to determine the meadow perimeter (bounded by tree islands and rock outcroppings) and to precisely locate each dig within the meadow. The length and width of each dig was then added to the map, allowing us to determine the total meadow area disturbed by grizzly bears, as well as the area disturbed in 1992 and 1993. All digs made prior to 1992 were 
lumped into one category, because we did not have an accurate method for backdating them. Nonetheless, a mosaic of older digs was apparent in each of the meadows, based on the array of digs of known ages and variations in plant distributions.

Distribution of plant species and ground cover.During 1994, three 100-m transects, one in the Lower Meadow and two in the Middle Meadow, were used to determine the distribution and percent cover of plant species, organic material, and bare ground in disturbed and undisturbed areas. Data were collected only from digs of known age (i.e., 1-3 yr old). The Lower Meadow transect bisected the meadow's length, and the starting point of the transect was randomly chosen. Because the Middle Meadow was much larger, it was stratified into two sections, each bisected by a transect with a randomly chosen starting point. Sampling sites were located every $10 \mathrm{~m}$ along each transect. A $0.5 \times 0.5$ $\mathrm{m}$ grid was strung on PVC pipe, creating 25 intersections of string. Each intersection was a sampling point where all types of ground cover were recorded. Raw numbers were multiplied by 4 to get the percent cover. Because plants often overlap under a sampling point (string intersection), total cover can sum to $>100 \%$.

Soil mineral nitrogen.-Ion exchange resin bags were placed randomly inside six bear digs and within the 2-m perimeter of undisturbed meadow surrounding each particular dig to determine relative amounts of $\mathrm{NH}_{4}^{+}-\mathrm{N}$ and $\mathrm{NO}_{3}^{-}-\mathrm{N}$ in the soil solution (Binkley and Matson 1983, Binkley et al. 1986). Four digs at Logan Pass (L1-L4, two each in the Middle and Lower Meadows) and two at Preston Park (P1-P2) were used. Dig ages were the following: L1, fresh (S. E. Tardiff and J. A. Stanford, personal observation); $\mathrm{P} 1,1 \mathrm{yr}(\mathrm{K}$. Johnson, personal communication); P2, unknown; L2, unknown; L3, unknown; L4, 10 yr (E. A. Hartley, personal communication).

Bags of nylon stocking containing $8.5 \mathrm{~g}$ wet mass of cation plus anion resin beads (J. T. Baker mixedbed ion exchange resin, VWR Scientific Products) were buried $10 \mathrm{~cm}$ deep and left to incubate in situ for 45 d during the summer of 1993 (a period that covered the majority of the growing season). Resin bags were retrieved in early October and allowed to air dry. Resin was extracted with $100 \mathrm{~mL}$ of $1 \mathrm{~mol} / \mathrm{L} \mathrm{KCl}$ and analyzed colorimetrically for $\mathrm{NH}_{4}^{+}-\mathrm{N}$ and $\mathrm{NO}_{3}^{-}-\mathrm{N}$ on a Technicon AutoAnalyzer II (Technicon 1978, 1979).

All statistical analyses on these data were done on $\log _{10}$-transformed data because the variance was significantly greater inside than outside digs $(P=0.028$, Wilcoxon signed-ranks test; SPSS Standard Version 1995). We expected $\mathrm{NH}_{4}^{+}-\mathrm{N}$ and $\mathrm{NO}_{3}^{-}-\mathrm{N}$ levels to be higher in digs than outside. We performed a two-way ANOVA on these data, using Dig (1-6) and Location (In or Out) as fixed effects, to test for the overall effect of bear digging on soil $\mathrm{NH}_{4}^{+}-\mathrm{N}$ and $\mathrm{NO}_{3}^{-}-\mathrm{N}$ (SPSS Standard Version 1995). For each of the six digs, we did $t$ tests comparing the amount of nitrogen inside digs with the amount outside of digs in undisturbed meadow.

Glacier lily nitrogen and carbon.-Glacier lily bulbs were randomly collected at Logan Pass in July 1994, while plants were in full flower, and again in August after shoot senescence. Plants were kept on ice and within $24 \mathrm{~h}$ were taken to the lab, where they were then washed and dried at $60^{\circ} \mathrm{C}$ for $48 \mathrm{~h}$. Bulbs were finely ground and percentages of nitrogen and carbon were determined by combustion on a Leco CHN Analyzer (Leco Corporation, St. Joseph, Michigan, USA). The carbon to nitrogen ratio $(\mathrm{C}: \mathrm{N})$ was calculated from those results. Water-soluble carbohydrates were determined following McClaugherty et al. (1985). We expected the percentage of $\mathrm{N}$ to be higher and the C:N to be lower in plants growing inside digs than in plants growing in undisturbed meadow. We also expected percentages of $\mathrm{N}$ and water-soluble carbohydrates to be higher in plants collected in August than in July (Mooney and Billings 1960). Data were tested for differences using $t$ tests (SPSS Standard Version 1995).

Glacier lily sexual reproduction.-The total number of seeds per glacier lily was determined in 1994. Numbers of seeds in capsules from all lilies growing inside all recent $(\sim 12)$ bear digs were counted at one meadow in Preston Park. Glacier lilies growing in undisturbed soil within the same meadow were randomly chosen and the number of seeds was counted until a similar number of plants had been examined inside and outside bear digs. A $t$ test was used to determine whether lilies inside digs produced significantly more seeds than those growing in undisturbed meadow (SPSS Standard Version 1995). Although seeds were not collected to test for viability, only large, filled seeds were counted.

Experimental digs.-In 1995, four sites in the Middle and Lower Meadows were randomly chosen as experimental dig sites. At these sites, 10 ion exchange resin bags were buried in the future disturbed and undisturbed areas, and were left for $\sim 1$ mo. These bags were removed in late September, and $1.5-\mathrm{m}^{2}$ digs were created by digging up the meadow sod in a manner similar to bear activity. In 1996, as soon as snow had melted off these sites, new resin bags were placed within each experimental dig and directly outside them (within $2 \mathrm{~m}$ of the dig perimeter) in undisturbed meadow. These resin bags were collected at the end of the 1996 growing season. Resin bags were air dried, extracted with $100 \mathrm{~mL}$ of $1 \mathrm{~mol} / \mathrm{L} \mathrm{KCl}$, and analyzed colorimetrically for $\mathrm{NH}_{4}^{+}-\mathrm{N}$ and $\mathrm{NO}_{3}^{-}-\mathrm{N}$ on a Technicon AutoAnalyzer II (Technicon 1978, 1979).

Statistical analyses of the experimental dig data were performed on $\log _{10}$-transformed data, to correct for nonnormality. We used $t$ tests to compare the amount of $\mathrm{NH}_{4}^{+}-\mathrm{N}$ and $\mathrm{NO}_{3}^{-}-\mathrm{N}$ inside experimental digs with that in adjacent, undisturbed meadow, both before and after the digging treatment. We also compared levels of nitrogen inside digs before and after digging, and levels of nitrogen outside of digs before and after the 
TABLE 1. Total amount of meadow disturbed annually by grizzly bears. Data are from three sites at Logan Pass in Glacier National Park, Montana, United States. Meadows were surveyed using a Topcan AT-F6 Autolevel (see Methods).

\begin{tabular}{|c|c|c|c|c|c|}
\hline \multirow[b]{2}{*}{ Site } & \multirow{2}{*}{$\begin{array}{l}\text { Total } \\
\text { area } \\
\left(\mathrm{m}^{2}\right)\end{array}$} & \multirow{2}{*}{$\begin{array}{c}\text { Total } \\
\text { area } \\
\text { dug } \\
\left(\mathrm{m}^{2}\right) \dagger\end{array}$} & \multicolumn{3}{|c|}{$\begin{array}{l}\text { Area dug }\left(\mathrm{m}^{2}\right) \text {, } \\
\text { by age of dig }\end{array}$} \\
\hline & & & $\begin{array}{l}\text { Before } \\
1992\end{array}$ & 1992 & 1993 \\
\hline Upper Meadow & 5300 & $\begin{array}{r}901 \\
(17.0)\end{array}$ & $\begin{array}{c}552 \\
(61.3)\end{array}$ & $\begin{array}{c}249 \\
(27.6)\end{array}$ & $\begin{array}{c}100 \\
(11.1)\end{array}$ \\
\hline Middle Meadow & 16400 & $\begin{array}{r}1176 \\
(7.2)\end{array}$ & $\begin{array}{c}605 \\
(51.4)\end{array}$ & $\begin{array}{c}365 \\
(31.0)\end{array}$ & $\begin{array}{c}206 \\
(17.5)\end{array}$ \\
\hline Lower Meadow & 5800 & $\begin{array}{c}702 \\
(12.1)\end{array}$ & $\begin{array}{c}283 \\
(40.3)\end{array}$ & $\begin{array}{c}394 \\
(56.1)\end{array}$ & $\begin{array}{c}25 \\
(3.6)\end{array}$ \\
\hline
\end{tabular}

$\dagger$ Numbers in parentheses refer to area dug as a percentage of the total area.

$\$$ Numbers in parentheses refer to percentage of the total area dug.

experimental digging, using paired $t$ tests (SPSS Standard Version 1995). We expected $\mathrm{NH}_{4}^{+}-\mathrm{N}$ and $\mathrm{NO}_{3}^{-}-\mathrm{N}$ levels in disturbed and undisturbed areas to be similar before the digging treatment, and higher inside the experimental digs after the digging treatment. We also performed a repeated-measures ANOVA on these data, using time (Before and After digging) and location (In or Out), grouped by dig (1-4), to test for the effect of the experimental digging on soil $\mathrm{NH}_{4}^{+}-\mathrm{N}$ and $\mathrm{NO}_{3}^{-}-\mathrm{N}$ (SPSS Standard Version 1995).

\section{RESULTS}

Meadow and bear dig mapping.-The total area disturbed by grizzly bears at the three Logan Pass meadows averaged $12.1 \%$ (Table 1). The amount of disturbance varied among years, although the majority of digging occurred in the aggregate, pre-1992 category. Each meadow contained $>35$ digs, some of which could not be accurately measured due to substantial obliteration by more recent digging. A propensity for recent digs to overlap with previously disturbed areas was apparent. Detailed analysis of the long-term spatial and temporal patterns of digs is not included here; our intent in this paper is to compare variables on a more local scale.

Distribution of plant species and ground cover.Grizzly bear digging created patches where distribution and abundance of ground cover differed from that of undisturbed areas in the same meadow (Fig. 2). Following disturbance, glacier lilies were the first plants to reappear in digs and they dominated the postdisturbance plant assemblage, accounting for $41 \%$ of the total plant cover. Of the total cover in digs, $65 \%$ was bare ground, and there was little measurable plant litter. In contrast, undisturbed meadows were covered by glacier lilies (24\%), plant litter (12\%), woodrush (15\%), Carex spp. (20\%), and other forbs and grasses (28\%).

Soil mineral nitrogen.-Dig and Location were significant main effects for $\mathrm{NH}_{4}^{+}-\mathrm{N}$ and $\mathrm{NO}_{3}^{-}-\mathrm{N}$; the in-

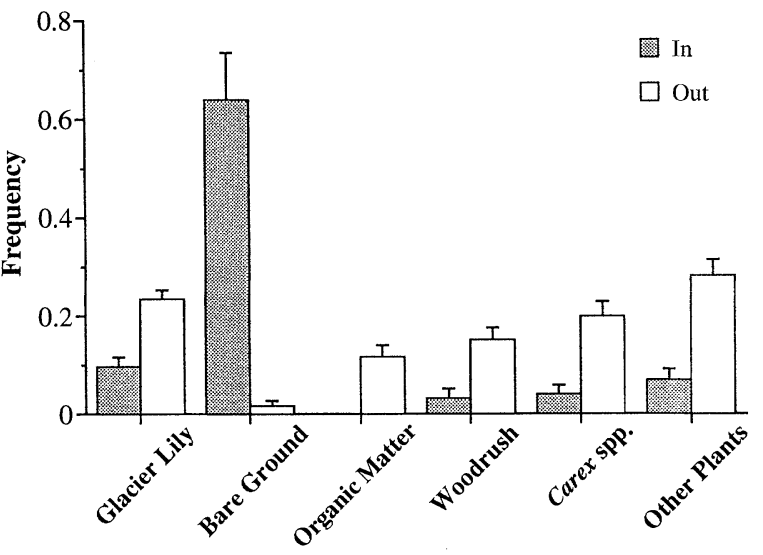

FIG. 2. Frequencies of ground cover by category inside digs (In) and in undisturbed meadow (Out) as determined along meadow transects. The high frequency of bare ground and glacier lilies inside digs is important to note, as well as the complete lack of organic material in digs. Data are means $+1 \mathrm{SD} ; n=7$ inside digs, and $n=46$ outside.

teraction term was not significant (Table 2). Although $\mathrm{NH}_{4}^{+}-\mathrm{N}$ was significantly higher inside digs than outside, only one individual dig (L4) had significantly higher $\mathrm{NH}_{4}^{+}-\mathrm{N}$ when compared to undisturbed meadow (Fig. 3A, $t$ test). Nitrate-N was significantly higher in four of the six individual digs when compared to surrounding, intact meadow (Fig. 3B, $t$ test). The 10-yrold dig (10S) also had significantly higher amounts of $\mathrm{NH}_{4}^{+}-\mathrm{N}$, and higher $\mathrm{NO}_{3}^{-}-\mathrm{N}$ that was near statistical significance $(P=0.057)$.

Glacier lily nitrogen and carbon.-Glacier lilies growing in digs were able to take advantage of increased levels of soil nitrogen by increasing the percentage of nitrogen in their tissue. During July, while the plants were in full bloom, and in August, after shoot senescence, lily bulbs from plants inside digs contained higher percentages of nitrogen than bulbs in undisturbed meadow $(P=0.002$ and $P=0.01$, respectively, $t$ test; Fig. 4A). Although water-soluble carbohydrates were significantly greater in bulbs inside digs in July, by August this difference was not apparent, because of high variance in one bulb from the undisturbed site $(P$ $=0.003$ and $P=0.34$, respectively; Fig. 4B). Bulbs from plants growing inside digs had a lower $C: N$ than

TABLE 2. Two-way ANOVA testing the effect of location (In and Out) and individual dig (1-6) on soil ammonium and nitrate availability in bear digs and undisturbed meadow.

\begin{tabular}{lrccrrrrr}
\hline \hline & \multicolumn{3}{c}{ Ammonium } & & \multicolumn{3}{c}{ Nitrate } \\
\cline { 2 - 3 } \cline { 6 - 8 } \multicolumn{1}{c}{ Source } & df & $F$ & $P$ & & df & $F$ & $P$ \\
\hline Location (L) & 1 & 5.576 & 0.022 & & 1 & 3.891 & 0.005 \\
Dig (D) & 5 & 4.729 & 0.001 & & 5 & 48.345 & 0.000 \\
L $\times$ D & 5 & 2.027 & 0.092 & & 5 & 1.812 & 0.129 \\
Error & 47 & & & & 47 & & \\
\hline
\end{tabular}




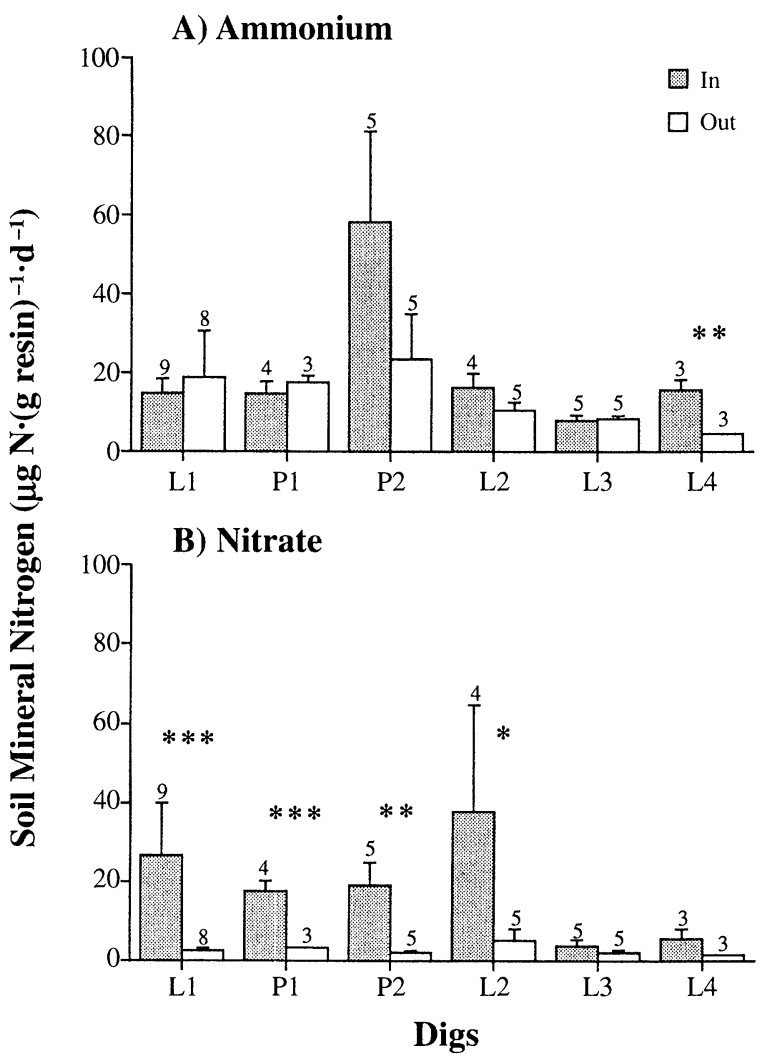

FIG. 3. Soil mineral nitrogen within six recent $(<5-y r-$ old) bear digs (In) and adjacent, undisturbed meadow (Out) at Logan Pass (L) and Preston Park (P). An ANOVA with Location (In or Out) and Dig (1-6) as the two fixed factors showed significance for the two main effects, both $\mathrm{NH}_{4}^{+}-\mathrm{N}$ (A) and $\mathrm{NO}_{3}^{-}-\mathrm{N}$ (B), but not for their interaction (Table 2). Asterisks indicate significant differences within individual digs $(* P \leq 0.05 ; * * P<0.01 ; * * * P<0.001 ; t$ test). Means +1 SD and the number of samples for each treatment are shown.

did plants from intact meadow in both months $(P=$ 0.002 and $P=0.02$, respectively; Fig. $4 \mathrm{C}$ )

Glacier lily sexual reproduction.-Glacier lilies growing in bear digs produced twice the number of seeds as plants growing in undisturbed meadow $(P=$ $0.0002, t$ test, Fig. 5).

Experimental digs.-Prior to the experimental digging treatment, soil in the area to be disturbed and the area to be left undisturbed at each site was sampled for $\mathrm{NH}_{4}^{+}-\mathrm{N}$ and $\mathrm{NO}_{3}^{-}-\mathrm{N}$. A paired-samples $t$ test across all four sites showed lower $\mathrm{NH}_{4}^{+}-\mathrm{N}$ in the future disturbed soil than in the future undisturbed soil $(P=0.029$, Fig. $6 \mathrm{~A})$. Individual $t$ tests for each dig revealed statistically higher values for the future undisturbed soil around Digs 1 and 4 (Fig. 6A). Nitrate-N had a different pattern. There was no significant difference between the future disturbed soil and the future undisturbed soil before digging ( $P=0.716$, paired-samples $t$ test), and no individual digs showed any statistically significant differences (Fig. 6B).
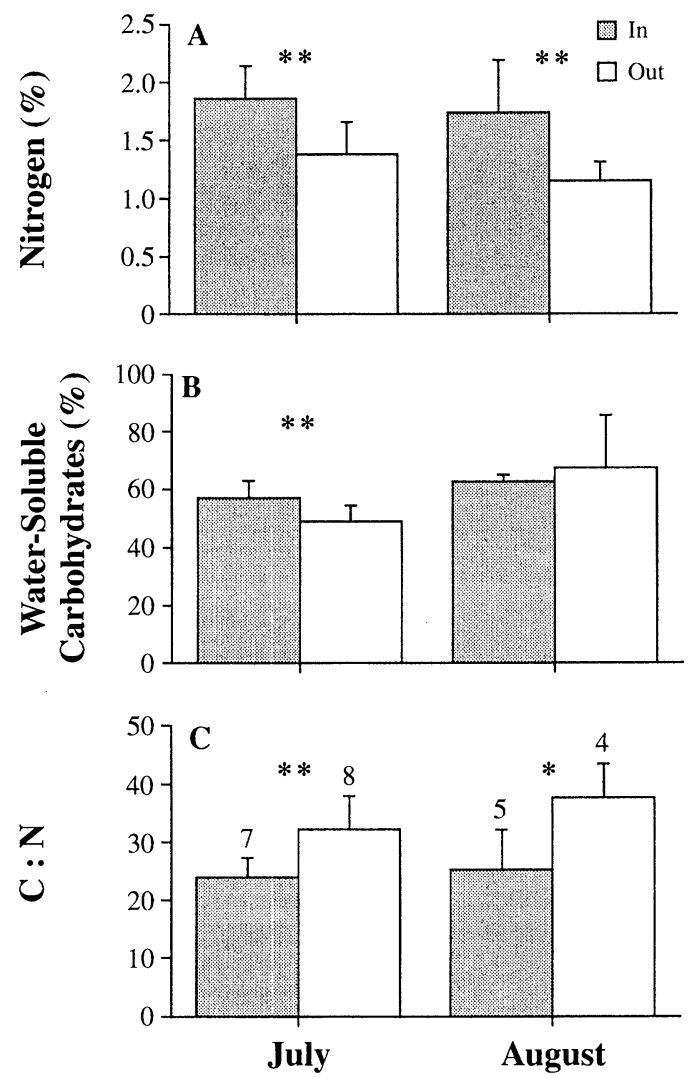

FIG. 4. Chemical composition of glacier lily bulbs inside digs (In) compared to bulbs from adjacent, undisturbed meadow (Out). Mean +1 SD are reported and the number of samples for each treatment are shown $(* P \leq 0.05$; * $P<0.01$; $t$ test). (A) Percentage of nitrogen was significantly higher in plants growing inside bear digs for both dates. (B) Bulbs inside digs contained higher percentages of water-soluble carbohydrates than did bulbs in undisturbed meadow in July, but not in August. (C) The carbon to nitrogen ratio (C:N) was significantly lower inside digs at both phenological stages.

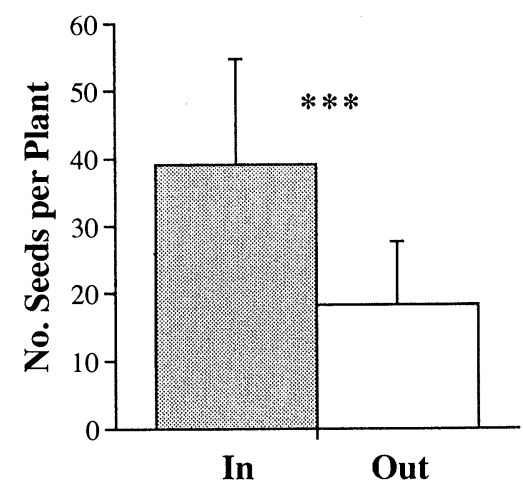

FIG. 5. Glacier lily seed production. Plants growing in grizzly bear digs (In) produced twice as many seeds as plants growing in undisturbed meadow (Out) $(* * * P<0.001 ; t$ test). Data are mean $+1 \mathrm{SD} ; n=37$ plants inside digs and $n=42$ plants outside digs. 
Ammonium

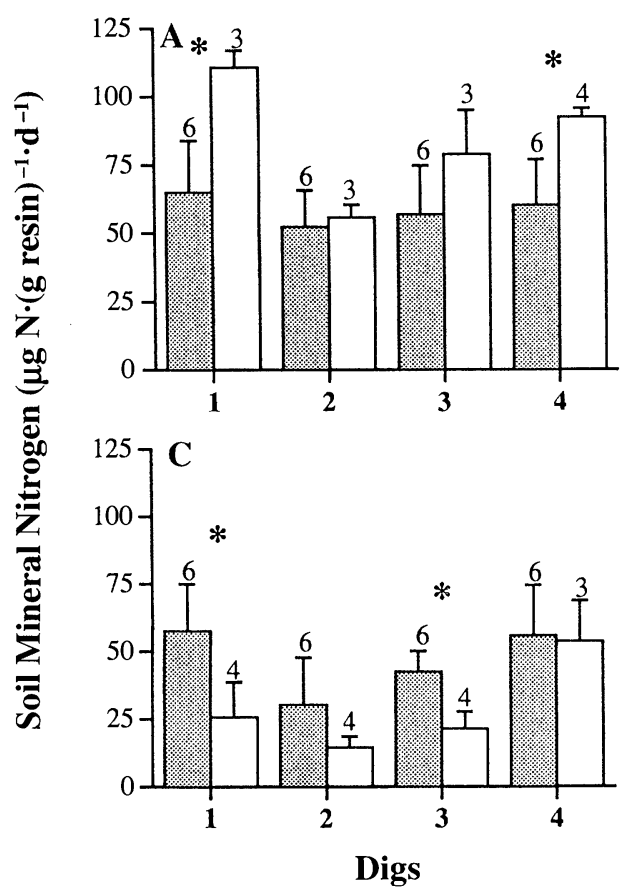

Nitrate
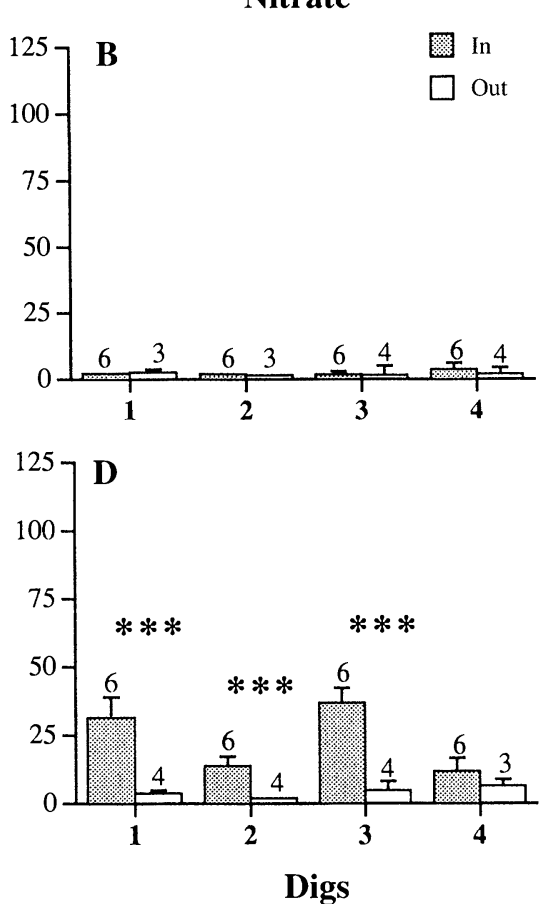

FIG. 6. Available soil mineral nitrogen in experimental digs determined using ion exchange resin bags, before (A, B) and after $(\mathrm{C}, \mathrm{D})$ the digging treatment and inside and outside the digs for $\mathrm{NH}_{4}^{+}-\mathrm{N}(\mathrm{A}, \mathrm{C})$ and $\mathrm{NO}_{3}^{-}-\mathrm{N}(\mathrm{B}, \mathrm{D})$. Asterisks indicate significant differences within individual digs $(* P \leq 0.05 ; * * P<0.01 ; * * * P<0.001 ; t$ test $)$. Means +1 SD and the number of samples for each treatment are shown. A repeated-measures ANOVA with Time (Before and After), Location (In and Out), and Dig (1-4) as fixed factors resulted in a significant Time $\times$ Location interaction (see Table 3, SPSS Standard Version 1995).

After our experimental digging, we again compared soil nitrogen inside and outside the digs using pairedsamples $t$ tests. Both $\mathrm{NH}_{4}^{+}-\mathrm{N}$ and $\mathrm{NO}_{3}^{-}-\mathrm{N}$ were higher inside digs than outside $(P=0.005$ and $P<0.001$, respectively; Fig. 6C, D). Digs 1 and 3 showed statistically higher levels of $\mathrm{NH}_{4}^{+}$-N inside than outside (Fig. $6 \mathrm{C})$. Digs 1,2 , and 3 contained more $\mathrm{NO}_{3}^{-}-\mathrm{N}$ than did adjacent, undisturbed meadow, and those differences were all highly significant (Fig. 6D). A repeated-measures ANOVA revealed a significant Time $\times$ Location interaction for both $\mathrm{NH}_{4}^{+}-\mathrm{N}$ and $\mathrm{NO}_{3}^{-}-\mathrm{N}$ (Table 3). The interaction indicates interdependence between the two

TABLE 3. Results from a repeated-measures ANOVA on the effects of time (Before and After) and location (In and Out), grouped by dig (1-4), on changes in soil ammonium and nitrate levels caused by the creation of experimental digs.

\begin{tabular}{lrrrrrrrr}
\hline \hline & \multicolumn{3}{c}{ Ammonium } & & \multicolumn{3}{c}{ Nitrate } \\
\cline { 2 - 4 } \cline { 7 - 8 } \multicolumn{1}{c}{ Source } & df & \multicolumn{1}{c}{$F$} & $P$ & & df & $F$ & $P$ \\
\hline Time (T) & 1 & 28.106 & 0.001 & & 1 & 73.159 & 0.000 \\
Location (L) & 1 & 0.643 & 0.446 & & 1 & 45.314 & 0.000 \\
$\mathrm{~T} \times \mathrm{D}$ & 3 & 1.113 & 0.399 & & 3 & 1.386 & 0.309 \\
$\mathrm{~L} \times \mathrm{D}$ & 3 & 0.454 & 0.721 & & 3 & 0.624 & 0.617 \\
$\mathrm{~T} \times \mathrm{L}$ & 1 & 8.500 & 0.019 & & 1 & 8.664 & 0.016 \\
$\mathrm{~T} \times \mathrm{L} \times \mathrm{D}$ & 3 & 0.765 & 0.545 & & 3 & 1.012 & 0.432 \\
Error & 8 & & & & 9 & & \\
\hline
\end{tabular}

variables, so we could not consider the importance of main effects.

The reason for measuring soil nitrogen availability both in and out of experimental digs and before and after the digging treatment, was to ensure that any significant differences seen over time were not simply due to between-year variation. We also used paired-sample $t$ tests to look at differences in the same location at the two different times. Ammonium- $\mathrm{N}$ levels inside the digs did not change significantly from before to after the digging treatment, whereas $\mathrm{NH}_{4}^{+}$- $\mathrm{N}$ levels in undisturbed meadow (directly outside dig sites) decreased significantly ( $P=0.074$ and $P<0.001$, respectively). Nitrate- $\mathrm{N}$ levels increased significantly after the digging treatment inside digs, but did not change in the undisturbed meadow $(P<0.001$ and $P=0.226$, respectively).

\section{Discussion}

Grizzly bear digging for glacier lily bulbs created patches within the subalpine meadow matrix that differed in plant species composition, soil mineral nitrogen abundance, and chemical content of the revegetating glacier lilies. Glacier lilies are the most numerous spring ephemeral in these meadows, and their perennial bulb life history strategy apparently allows 
them to respond most quickly to this digging disturbance, when they are not eaten. Bears miss many glacier lily bulbs, and these individuals regrow in the following year, becoming the first plants to revegetate bear digs.

Increased soil mineral nitrogen in bear digs may have been caused by increased wetting and drying episodes following the physical disturbance of soil aggregates and the removal of plants and litter (Birch 1958, 1960). Soil temperature may have increased due to the darkening of soil albedo caused by the exposure of mineral soil, and due to removal of the insulating layer of organic material. Plant removal has been shown to cause an increase in nitrification, perhaps because plants are better than competing autotrophic nitrifiers at taking up $\mathrm{NH}_{4}^{+}-\mathrm{N}$, and this could also account for increased $\mathrm{NO}_{3}^{-}-\mathrm{N}$ in digs (Zak et al. 1990, Kaye and Hart 1997). The 10-yr-old dig (L4) had significantly higher amounts of $\mathrm{NH}_{4}^{+}-\mathrm{N}\left(\mathrm{NO}_{3}^{-}-\mathrm{N}\right.$ was nearly statistically significant) than the meadow surrounding it, indicating the potential for long-term consequences of bear digging. Results from the experimental digs corroborated our findings from the natural bear digs. The physical action of digging led to increased $\mathrm{NH}_{4}^{+}-\mathrm{N}$ and $\mathrm{NO}_{3}^{-}-\mathrm{N}$ in experimental digs, with $\mathrm{NO}_{3}^{-}-\mathrm{N}$ having the stronger response. Therefore, bear excretion was not a factor causing increased mineral nitrogen levels, nor are bears necessarily choosing sites already high in $\mathrm{N}$.

Increased seed production by glacier lilies growing in digs could be the result of reduced competition for limiting resources, e.g., nitrogen (Stephenson 1981, Willson and Burley 1983). Increased availability of mineral nitrogen following bear digging may directly cause increased seed production, potentially affecting plant fitness. In addition, glacier lilies produce heavy seeds without elaisomes, unlike many eastern U.S. congeners. Seed dispersal is restricted to a $1 \mathrm{~m}$ radius around the parent plant (Weiblen and Thomson 1995). Therefore, most seeds produced by lilies in bear digs fall onto bare soil, which is ideal for germination and establishment of Erythronium seedlings (Caldwell 1969, E. grandiflorum; Hughes 1992, E. americanum). In our study meadows, grizzly bear digging for glacier lilies is the primary cause of patches of bare mineral soil, apparently ideal places for colonization by the next generation of these long-lived lilies. Selection in this system could work to minimize dispersal distance in glacier lilies, a suggestion recently made by Thomson et al. (1996).

The higher nitrogen and water-soluble carbohydrate content of bulbs regrowing in digs and the reduction in relative abundances of other plant species strongly suggest that glacier lilies were able to take advantage of increased nitrogen availability and decreased competition. Increases in tissue nitrogen and carbohydrate would also tend to make bulbs in digs more nutritious and digestible for bears. In addition, tilled soils are easier for bears to dig in, although glacier lilies are less abundant in digs than in undisturbed meadow. Grizzly bears do revisit previously disturbed sites, and changes in bulb nutritional content provide a possible explanation for this behavior. Ease of digging, along with distance to forest cover, has been shown to be important to grizzly bear choice of digging sites for biscuitroots (Lomatium cous), but density of preferred plants is not important (Mattson 1997).

The importance of spring ephemerals such as glacier lilies to early-season nitrogen retention also was observed in hardwood forests containing a congener of the glacier lily, E. americanum. This species was shown to play a significant role in the uptake of mineral nitrogen released during snow melt, leading to the vernaldam hypothesis (Muller and Bormann 1976, Muller 1978). Due to the high nitrogen requirements and early growth of E. americanum, individuals sequestered significant amounts of nitrogen and potassium found in melting snow that would otherwise have passed through the soil into streams and been lost to the terrestrial system. Although the microbial community has since been shown to immobilize greater amounts of mineral nitrogen than do spring ephemerals, these plants are still important in reducing system nitrogen losses (Zak et al. 1990).

Glacier lilies probably play a similar nitrogen-sequestering role in this subalpine, western U.S. ecosystem. We have not quantified nitrogen mass balance in these meadows, but we do know that soluble N:P increases dramatically as one moves downhill through the watershed, suggesting that the terrestrial system is losing nitrogen (Ellis and Stanford 1988). The influence of grizzly bear digging on the retention of $\mathrm{N}$ in subalpine meadows undoubtedly depends on the time frame. Over the short-term $(<10 \mathrm{yr})$, nitrogen could be lost to the system due to the increases in $\mathrm{NO}_{3}^{-}-\mathrm{N}$ following digging, because $\mathrm{NO}_{3}^{-}-\mathrm{N}$ is water soluble and readily leached from the soil. The long-term answer to this question depends on the successional plant dynamics occurring in these subalpine meadows. If disturbance is necessary for the maintenance of glacier lilies (a low C:N species) in the meadow plant assemblage, then a meadow without bear-disturbed patches may eventually lose its carpet of glacier lilies. As this happens, plant species with higher $\mathrm{C}: \mathrm{N}$ ratios might eventually dominate the community, resulting in further decreases in mineral nitrogen availability to the terrestrial system. Cross-site comparisons would be needed to test this hypothesis.

We documented the potential maintenance and enhanced fitness of a preferred forage species in this subalpine meadow ecosystem through the action of grizzly bear digging. This lends support to the idea of herbivores as positive functional switches in relation to ecosystem processes (Pastor and Naiman 1992). Although other researchers have speculated on the implications of grizzly bear digging (Hamer and Herrero 1987, Butler 1992, Mattson 1997), we are the first to show the 
consequences of bear digging on the ecology of the preferred species and the ecosystem in which they live. Digging increased the nutrient content and seed production of glacier lilies, a preferred forage species that also revegetates digs. The return of bears to patches that they have previously disturbed may be common, and adds increasing complexity to long-term soil and plant dynamics at these sites. Grizzly bears must be added to the growing list of species that act as strong interactors, or ecosystem engineers (Jones et al. 1994). For the meadows of the high country of Glacier $\mathrm{Na}$ tional Park, Montana, grizzly bears mediate an unusual, positive feedback relationship, which has long-term implications for successional dynamics of subalpine meadows.

\section{ACKNOWLEDGMENTS}

We thank R. Callaway, B. Dewey, B. Ellis, J. Greenlee, S. Hitchcox, M. Marler, J. Pastor, G. Poole, H. Sieck, E. Wohl, A. Young, and C. Zabinski for help with data collection and manuscript preparation. The staff of Glacier National Park, Montana, United States provided helpful logistical assistance and a collecting permit. The Natural Resources Research Institute, University of Minnesota, Duluth, Minnesota kindly performed all of the plant chemical analyses. This research was completed in partial fulfillment of the requirements for the degree Doctor of Philosophy at the University of Montana for S. Tardiff. Two anonymous reviewers provided useful comments on the manuscript. Research was funded by the Jessie M. Bierman Professorship at the Flathead Lake Biological Station, the University of Montana, and by Grant DEB-9509597 of the Ecosystem Program of the National Science Foundation.

\section{Literature Cited}

Binkley, D., J. Aber, J. Pastor, and K. Nadelhoffer. 1986. Nitrogen availability in some Wisconsin forests: comparisons of resin bags and on-site incubations. Biological Fertility of Soils 2:77-82.

Binkley, D., and P. Matson. 1983. Ion exchange resin bag methods for assessing forest soil nitrogen availability. Soil Science Society of America Journal 47:1050-1052.

BioScience (AIBS). 1988. How animals shape their ecosystems. BioScience 38:750-800.

Birch, H. F. 1958. The effect of soil drying on humus decomposition and nitrogen availability. Plant and Soil 10: 9-31.

1960. Nitrification in soils after different periods of dryness. Plant and Soil 12:81-96.

Butler, D. R. 1992. The grizzly bear as an erosional agent in mountainous terrain. Zeitschrift fur Geomorphologie 36: 179-189.

Caldwell, M. L. H. 1969. Erythronium: comparative phenology of alpine and deciduous forest species in relation to environment. American Midland Naturalist 82:543-558.

Chapman, J. A., J. I. Romer, and J. Stark. 1953. Ladybird beetles and army cutworm moths as food for grizzly bears in Montana. Ecology 36:156-158.

Choate, C. M., and J. R. Habeck. 1967. Alpine plant communities at Logan Pass, Glacier National Park. Proceedings of the Montana Academy of Sciences 27:36-54.

Coppock, D. L., J. E. Ellis, J. K. Detling, and M. I. Dyer. 1983. Plant-herbivore interactions in a North American mixed-grass prairie II. Responses of bison to modification of vegetation by prairie dogs. Oecologia 56:10-15.

Craighead, J. J., and J. A. Mitchell. 1982. Grizzly bear. Pages 515-556 in J. A. Chapman and G. A. Feldhamer, editors.
Wild mammals of North America: biology, management, and economics. John Hopkins University Press, Baltimore, Maryland, USA.

Edge, W. D., C. L. Marcum, and S. L. Olson-Edge. 1990. Distribution and grizzly bear, Ursus arctos, use of yellow sweetvetch, Hedysarum sulphurescens, in northwestern Montana and southeastern British Columbia. Canadian Field Naturalist 104:435-438.

Ellis, B. K., and J. A. Stanford. 1988. Nutrient subsidy in montane lakes: fluvial sediments versus volcanic ash. Verhandlungen der Internationalen Vereinigung fur Theoretische und Angewandte Limnologie 23:327-340.

Hamer, D., and S. Herrero. 1987. Grizzly bear food and habitat in the front ranges of Banff National Park, Alberta. International Conference on Bear Research and Management 7:199-213.

Hamer, D., S. Herrero, and K. Brady. 1991. Food and habitat used by grizzly bears, Ursus arctos, along the continental divide in Waterton Lakes National Park, Alberta. Canadian Field-Naturalist 105:325-329.

Hartley, E. A. 1976. Man's effects on the stability of alpine and subalpine vegetation in Glacier National Park, Montana. Dissertation. Duke University, Durham, North Carolina, USA.

Holcroft, A. C., and S. Herrero. 1984. Grizzly bear digging for Hedysarum sulphurescens roots in southwestern Alberta. Canadian Journal of Zoology 62:2571-2575.

Hughes, J. W. 1992. Effect of removal of co-occurring species on distribution and abundance of Erythronium americanum (Liliaceae), a spring ephemeral. American Journal of Botany 79:1329-1336.

Huntly, N. 1991. Herbivores and the dynamics of communities and ecosystems. Annual Review of Ecology and Systematics 22:477-504.

Huntly, N., and R. Inouye. 1988. Pocket gophers in ecosystems: patterns and mechanisms. BioScience 38:786-93.

Jones, C. J., and J. H. Lawton, editors. 1995. Linking species and ecosystems. Chapman and Hall, New York, New York, USA.

Jones, C. J., J. H. Lawton, and M. Shachak. 1994. Organisms as ecosystem engineers. Oikos 69:373-386.

Kawano, S., A. Hiratsuka, and K. Hayashi. 1982. Life history characteristics and survivorship of Erythronium japonicum. V. The productive and reproductive biology of flowering plants. Oikos 38:129-149.

Kaye, J. P., and S. C. Hart. 1997. Competition for nitrogen between plants and soil microorganisms. Trends in Ecology and Evolution 12:139-143.

Kendall, K. C. 1983. Use of pine nuts by grizzly and black bears in the Yellowstone area. International Conference on Bear Research and Management 5:166-173.

Krueger, K. 1986. Feeding relationships among bison, pronghorn, and prairie dogs: an experimental analysis. Ecology 67:760-770.

Mace, R., and C. Jonkel. 1986. Local food habits of the grizzly bear in Montana. International Conference on Bear Research and Management 6:105-110.

Maschinski, J., and T. G. Whitham. 1989. The continuum of plant responses to herbivory: the influence of plant association, nutrient availability, and timing. American Naturalist 134:1-19.

Mattson, D. J. 1997. Selection of microsites by grizzly bears to excavate biscuitroots. Journal of Mammalogy 78:228238.

Mattson, D. J., C. M. Gillin, S. A. Benson, and R. R. Knight. 1991. Bear feeding activity at alpine insect aggregation sites in the Yellowstone ecosystem. Canadian Journal of Zoology 69:2430-2435.

Mattson, Jr., W. J. 1980. Herbivory in relation to plant ni- 
trogen content. Annual Review of Ecology and Systematic: 11:119-162.

McClaugherty, C. A., J. Pastor, J. D. Aber, and J. M. Melillo. 1985. Forest litter decomposition in relation to soil nitrogen availability and litter quality. Ecology 66:266-275.

Mooney, H. A., and W. D. Billings. 1960. The annual carbohydrate cycle of alpine plants as related to growth. American Journal of Botany 47:594-598.

Muller, R. N. 1978. The phenology, growth, and ecosystem dynamics of Erythronium americanum in the northern hardwood forest. Ecological Monographs 48:1-20.

Muller, R. N., and F. H. Bormann. 1976. Role of Erythronium americanum Ker. in energy flow and nutrient dynamics of a northern hardwood forest ecosystem. Science 193:11261128.

Paige, K. N. 1992. Overcompensation in response to mammalian herbivory: from mutualistic to antagonistic interactions. Ecology 73:2076-2085.

Paige, K. N., and T. G. Whitham. 1987. Overcompensation in response to mammalian herbivory: the advantage of being eaten. American Naturalist 129:407-416.

Pastor, J., B. Dewey, R. J. Naiman, P. F. McInnes, and Y. Cohen. 1993. Moose browsing and soil fertility in the boreal forests of Isle Royale National Park. Ecology 74: $467-480$.

Pastor, J., and R. J. Naiman. 1992. Selective foraging and ecosystem processes in boreal forests. American Naturalist 139:690-705.

$\rightarrow$ Phillips, M. K. 1987. Behavior and habitat use of grizzly bears in northeastern Alaska. International Conference on Bear Research and Management 7:159-167.

Platt, W. J., and I. M. Weis. 1977. Resource partitioning and competition within a guild of fugitive prairie plants. American Naturalist 111:479-513.

Ross, A. 1855. The fur hunters of the Far West; a narrative of adventures in the Oregon and Rocky Mountains. Volume 2: 120. Smith, Elder and Company, 65, Cornhill, London, UK.
Servheen, C. W. 1983. Grizzly bear food habits, movements, and habitat selection in the Mission Mountains, Montana. Journal of Wildlife Management 47:1026-1035.

Singer, F. J. 1978. Seasonal concentrations of grizzly bears, North Fork of the Flathead River, Montana. Canadian FieldNaturalist 92:283-286.

SPSS. 1995. Standard Version 7.0. SPSS, Chicago, Illinois, USA.

Stephenson, A. G. 1981. Flower and fruit abortion: proximate causes and ultimate functions. Annual Review of Ecology and Systematics 12:253-279.

Technicon. 1978. Ammonia in water and seawater. Industrial Method 154-71W/B, Technicon Industrial Systems, Tarrytown, New York, USA.

. 1979. Nitrate and nitrite in water and seawater. Industrial Method 158-71W/A, Technicon Industrial Systems, Tarrytown, New York, USA.

Thompson, J. N. 1994. The coevolutionary process. University of Chicago Press, Chicago, Illinois, USA.

. 1996. Evolutionary ecology and the conservation of biodiversity. Trends in Ecology and Evolution 11:300-303.

Thomson, J. D., G. Weiblen, B. A. Thomson, S. Alfaro, and P. Legendre. 1996. Untangling multiple factors in spatial distributions: lilies, gophers, and rocks. Ecology 77:16981715.

Weiblen, G. D., and J. D. Thomson. 1995. Seed dispersal in Erythronium grandiflorum (Liliaceae). Oecologia 102:211219.

Whicker, A. D., and J. K. Detling. 1988. Ecological consequences of prairie dog disturbances. BioScience 38:778785 .

Willson, M. F., and N. Burley. 1983. Mate choice in plants: tactics, mechanisms, and consequences. Monograph in Population Biology 19, Princeton University Press, Princeton, New Jersey, USA.

Zak, D. R., P. M. Groffman, K. S. Pregitzer, S. Christenson, and J. M. Tiedje. 1990. The vernal dam: plant-microbe competition for nitrogen in northern hardwood forests. Ecology 71:651-656. 